\title{
ON PRESERVATION AND DEVELOPMENT OF ESTONIAN AS A RESEARCH LANGUAGE IN ANTHROPOLOGY - THE ROLE OF THE YEARBOOKS OF THE ESTONIAN ANTHROPOMETRIC REGISTER (1998-2002) IN IT
}

\author{
JaAn Kasmel, Tiiu Kasmel \\ Centre for Physical Anthropology, University of Tartu, Tartu, Estonia
}

\begin{abstract}
A few years after its foundation (1993), the Centre for Physical Anthropology at the University started cooperation with the Estonian Anthropometric Register. Together, it was decided to publish the Estonian-language Yearbook of the Estonian Anthropometric Register to preserve and develop Estonian as the language of research in anthropology. By that time, the Centre for Physical Anthropology had also started to publish the collection Papers on Anthropology in English.

The article provides an overview of the Yearbooks of the Estonian Anthropometric Register 1998-2002. The covers of the yearbooks were designed by Michael Walsh and the language editor was Leelo Jago. From 1999, all the articles were accompanied by summaries in English. The Yearbook of 2002 is indexed in SPORTDiscus database. All the Yearbooks were printed by University of Tartu Press.

The overview presents the cover, title page and contents of the first Yearbook; the following Yearbooks are represented only by the contents and summaries of prefaces by editor-in-chief Helje Kaarma.

General characterisation of the five Yearbooks: 1129 pages in total, 125 published publications, 125 researchers as their first authors, in addition to them 171 co-authors; thus, 296 researchers participated as authors of articles. Actually, these numbers turn out to be smaller, as the number of authors of articles ranges between one and eight.
\end{abstract}


Based on this, a table has been compiled about the distribution of articles per number of authors.

The second part of the overview presents, as Tables, the distribution of articles according to their first authors by years and the distribution of articles between the authors from Tartu and Tallinn, and from the institutions of these towns. We also add the list of co-authors and the numbers of their participation in the articles of the Yearbooks.

Based on the overview, it can be said that the five Yearbooks of the Estonian Anthropometric Register published from 1998-2002, their 125 publications and 56 researchers as first authors and their 77 co-authors, thus a total of 133 authors have a definite and constant role and significance in the preservation and development of Estonian as a language of research in this period.

The question arises whether there is any other branch of research in Estonia, the representatives of which would have done anything similar in these years or earlier for the preservation and development of Estonian as a research language in their area, not only published articles in English.

Keywords: Centre for Physical Anthropology at the University of Tartu; Yearbooks of the Estonian Anthropometric Register; Estonian as research language in anthropology; Helje Kaarma

\section{PART I}

For several reasons, researchers from Estonia have published their research papers on anthropology in Latin, German, Russian, French, Estonian, and finally, in English, the main language of research in the present-day world, as it has become the common language of researchers.

It is known how, during this period, some journals in national languages have switched to English. To begin with, summaries in English were required, then articles were translated into English, and finally, only papers written in English were admitted as contributions to journals [7].

English has exerted a remarkable influence on the once strong and independent German-language world of research - today, English is the main working language for more than three quarters of German natural scientists [8].

Finnish scientific and academic life turned to English in the 1950s when exchange programmes with US universities began [9].

The Anglo-German bibliographic databases of the initial years of the 21st century show that English dominates clearly in all areas of research, e.g. in natural sciences $87.2 \%$ of publications are in English, in social sciences the proportion is somewhat smaller, $82.5 \%$ [1]. 
Against the background of such general developments, English is inarguably becoming more predominant in research activities in Estonia as well. Still, it should be considered how the Estonian language develops as a language of research and what should be done so that the university teaching staff and students, when writing their research papers or presenting their results, could use immaculate Estonian language.

Although throughout the 19th century, Tartu had a world-class university, we did not have Estonian-speaking intelligentsia and even academic Estonian language in the early 20 th century.

Therefore, after gaining independence, the Republic of Estonia considered it necessary to make Estonian the language of tuition at the University of Tartu.

Along with developing international research, the creation of Estonianspeaking intelligentsia was set as a major aim to enable the state to function and develop in Estonian. The objective of the Republic of Estonia is the preservation of the Estonian people, the Estonian language and the Estonian culture. This it is not possible without Estonian intellectuals.

An intellectual is a carrier of the literary language. If Estonian intellectuals' linguistic value assessments are shaped by some other language instead of the mother tongue, what is it then that would keep the Estonian language and Estonian-language culture alive? The extinction of languages always begins from education and intellectuals [11].

At present, approximately 7000 languages are spoken in the world. The Estonian language is not among the one third of languages that are in direct danger of extinction, as the number of speakers of Estonian is about a million, Estonian has a status of the official language and is one of the 24 official working languages of the European Union [14].

What can be done to keep the Estonian language from becoming only a home language or falling into the danger of direct extinction - would we be happy about this kind of development?

Action is needed, as in the digital age some changes, including the decline of smaller languages, can happen very quickly.

In the early 20th century, Professor of Anatomy A. Rauber planned founding an institute of anthropology at the University of Tartu but did not get any support from the University. In the years before World War II, Prof. Juhan Aul, the grand old man of our anthropology, considered it necessary to found an anthropological research institute at the Estonian Academy of Sciences but did not succeed either [13].

In the first years after Estonian regained independence, during the reforms of the University of Tartu, the Centre for Physical Anthropology was created 
as a separate structural unit of the Institute of Anatomy at the Faculty of Medicine of the University of Tartu. The Centre was founded at the initiative of Prof. Helje Kaarma by the order of Rector Prof. Peeter Tulviste (1945-2017) on 18 July 1993.

The aim of the Centre was to direct and coordinate teaching and research of anthropology at the University and the whole of Estonia and to supervise degree studies in the speciality.

The Centre for Physical Anthropology unites experts in different specialities from the whole of Estonia who are interested in anthropology. The Centre became a member of the European Anthropological Association [10].

The series of anthropology conferences in Tartu continued. During the first five years of the Centre, three collections of conference abstracts were published in English and two collections of articles in English - Papers on Anthropology VI and VII (respectively in 1995 and 1997). The articles of the latter collection were internationally peer-reviewed. By today, this collection has become the journal Papers on Anthropology, which is published twice a year and is also available electronically [12].

In 1995, a new structure became operative at the Centre - the Estonian Anthropometric Register, financed from the state budget. The Register was established in cooperation with the Bureau of Medical Statistics. The Anthropometric Register was meant for storing the anthropometric data of the whole of Estonia [10].

By that time, the Centre for Physical Anthropology had published the collection Papers on Anthropology VI in English, and the next issue was being compiled.

Before that, the anthropologists of the University had published their papers in the series of the Transactions of Tartu State University Antropoloogia-alased töö (Труды по антропологии), по. 1-4, 1964-1988.

In the first three collections, if the article was in Estonian, the summary was in Russian and in German or English; if the article was in Russian, the summary was in Estonian and in German or English; if the article was in German, the summary was in Estonian and Russian. The fourth collection was entirely in Russian.

In the 1980s, several changes took place in Estonian education and research. On 30 September 1988, the university council adopted new statutes, according to which the name of the university was changed into the University of Tartu. The University of Tartu became the national university of Estonia. The Transactions of Tartu State University were renamed the Transactions of the University of Tartu. 
The publication of Papers on Anthropology continued, now with the title in English, but the serial numbers of the series that had its beginning in 1964 with its old name Antropoloogia-alaseid töid did not change.

Issue 951 of Transactions of the University of Tartu, Papers on Anthropology $V$ was published in English on 130 pages in 1992, thus after the restoration of Estonia's independence [12].

As can be seen, the language of this collection also finally changed to English, similarly to research literature elsewhere in the world.

Therefore, to develop and preserve Estonian as a research language in anthropology, the Centre for Physical Anthropology and the researchers interested in anthropology decided to found the Yearbook of the Estonian Anthropometric Register (Eesti Antropomeetriaregistri Aastaraamat) that was published in Estonian.

The first Yearbook of the Estonian Anthropometric Register was published in 1998. Its cover and title page are shown respectively in Figures 1 and 2.
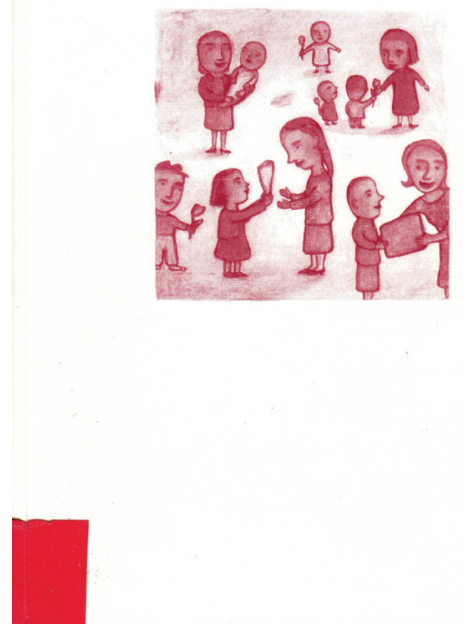

TARTU 1998

Figure 1. Cover of the Yearbook of the Estonian Anthropometric Register 1998 [2].

Figure 2. Title page of the Yearbook of the Estonian Anthropometric Register 1998 [2]. 
As the Yearbook is in Estonian, we publish the introduction by its editor-inchief, Prof. H. Kaarma here in English: "Hereby, the new periodical publication, Yearbook of the Estonian Anthropometric Register, has come out in print. We hope to converge around it everyone interested in anthropology: practising doctors, biologists, mathematicians, experts of health promotion, and medical researchers of narrower specialities. Everyone's efforts are necessary and welcome to find the constitutional peculiarities of healthy and sick people, and their significance in biology, medicine and health promotion. [2]"

Below, we present the contents of the first Yearbook in English [2]:

Ene-Margit Tiit. On the Anthropometric Register. 9

Juta Varjas, Helje Kaarma. Relations between clinical anthropometric data and the course of pregnancy and parturition

Helje Kaarma, Jana Peterson, Jaan Kasmel, Gudrun Veldre, Katrin

Saluvere, Liidia Saluste. Experience of five years of work of the Centre for Physical Anthro-

pology at the University of Tartu and its further plans ...........................................................2

Valdar Parve. Medical anthropology of the Continental European tradition............................... 26

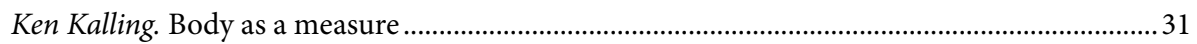

Lagle Suurorg. Anthropometric parameters of children aged one year.............................................. 36

Alvi Tellmann. Estonians' birth weight according to mother's place of residence 1992-1996 ... 43

Anatoli Landõr, Servi Täll, Nadežda Ignatjeva. Morphological features of residents of South Estonia at different ages.

Tatjana Kums. Functional status of gymnasts' skeletomuscular system

and its dependence on some kinanthropometric indicators

Mart Lintsi, Jüri Liivamägi, Anu Aluoja, Liidia Saluste, Säde Koskel. Preliminary notes on temperament and its variants in young men of in the final year of Tartu upper secondary schools.

Eevi Maiste. Normal measurements and remodulation of the left ventricle ...................................66

Jana Peterson, Jüri Liivamägi, Liidia Saluste, Säde Koskel. Body build and temperament........... 71

Pille Kaldmäe. Children's lung function depending on body build .............................................. 78

Merileid Saava, Karin Lilienberg, Liidia Tšaiko, Reet Sink. Relations between the main anthropometric parameters and nutrition at school age.

Olga Volozh, Eleonora Solodkaja, Jelena Abina, Aleksander Olferjev. Relation of blood pressure and lipids with body mass index .....

Merileid Saava, Alvi Tellmann, Karin Neilinn-Lilienberg, Liidia Tšaiko. School students' physical and sexual development in relation to provision of vitamins: Results of two years of vitaminisation

Virve Kask. On predictive values of clinical anthropometry in the work of children's and adolescents' gynecologists

Leiu Heapost On Estonians' anthropological peculiarities

Raini Stamm, Meelis Stamm, Säde Koskel. Relations of age and anthropometric parameters of girl volleyballers of Class B with their age and physical abilities 
Ülle Kirss, Maie Thetloff. Characterisation of distribution of body height, mass and body mass index in Estonian infants ( $0-2$ years)

Jaan Kasmel, Tiiu Kasmel. On Prof. Georg Balk, the first lecturer in anthropology at the University of Tartu.

Kersti Loolaid, Helje Kaarma, Valve Loolaid, Liidia Saluste. On body build and nutrition habits of 15-16-year-old schoolgirls.

Eve Pihl, Toivo Jürimäe, Taie Kaasik. Comparison of anthropometric parameters and physical performance of young and middle-aged physically active and non-active men

Leila Oja, Toivo Jürimäe. Changes in anthropometric parameters of kindergarten children during one academic year

Jaan Loko, Rein Aule, Tõnu Sikkut, Atko Viru, Jaan Ereline. On prevention of motor disorders during the pubertal period in girls.

Gudrun Veldre, Monika Laurits. Main indicators of development and nutrition peculiarities of 11-16-year-old children of Palamuse rural municipality

Next, we present, as illustration the contents pages of all the Yearbooks of the Estonian Anthropometric Register published from 1999-2002.

\section{CONTENTS}

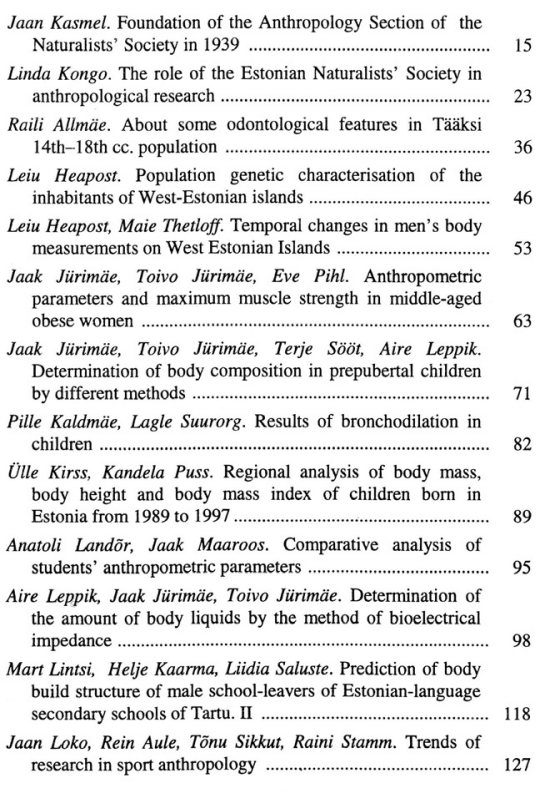

Figure 3. Contents of the Yearbook of the Estonian Anthropometric Register 1999, p. 9 [3].

\section{Contents}

Kersti Loolaid, Valve Loolaid, Helje Kaarma, Liidia Saluste. Dietary intake and body structure of secondary school girls from Tartu ............................................................... 133

Eevi Maiste. On the importance of clinical anthropometry in

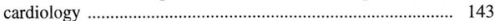

Leila Oja. Toivo Jürimäe. Changes in two years in the anthropometric parameters of initially six-year-old children ............. 150

Jana Peterson. Analysis of anthropometric data of young women aged 17-23 years .................................................... 163 Galina Sarap. Initial odontoglyphical data of Estonians in relation to the problems of ethnogenesis ................................ 173

Raini Stamm, Meelis Stamm, Säde Koskel. The anthropometric factor in evaluating girls' proficiency in volleyball ................. 190 Erki Tammiksaar. Karl Ernst von Baer as an anthropologist ....... 202 Alvi Tellmann, Viktoria Serkina. Birthweight of Estonian children from 1992 to 1997 ................................................ 208

Gudrun Veldre. Changes in the body build of 8-9-year-old children in Tartu ............................................................... 219

Olga Volož, Eleonora Solodkaja, Gundega Goldstiene, Jelena Abina, Reet Kaup, Dmitri Listopad, Tiiu Kaljuste, Aleksander Dejev. Significance of anthropology in population studies …………………............................................ 226

Enn Vatter. Registers and other databases ................................ 233

Figure 4. Contents of the Yearbook of the Estonian Anthropometric Register 1999, p. 10 [3]. 


\section{CONTENTS}

Tiia Bakler. Anthropometric parameters and body composition of basketball players ........................................ 17

Jaak Jürimäe, Toivo Jürimäe, Tönu Körge. Relationships between anthropometric variables and different strength characteristics in 14-16-year-old paddlers

Toivo Jürimäe, Aire. Leppik, Jaak Jürimäe, Vaino Hussar. Relationships between anthropometric parameters and physical activity in prepubertal gils

Helje Kaarma, Kandela Õun, Aivar Ehrenberg, Ly Jaanus. Inpatients' database at the Women's Hospital of Tartu University

Jaan Kasmel, T. Kasmel. Prof. Juhan Aul's first course of lectures on anthropology in the spring term of 1940

Ülle Kirss, Kandela Õun. Mean values of body weight, body height and head circumference of $0-2$-year-old children in Estonia. Application of birth data for predicting these measurements

Karin Lilienberg, Merileid Saava. The correlation of anthropometric characteristics of Tallinn schoolchildren with blood plasma lipids and arterial blood pressure ....

Mart Lintsi, Helje Kaarma, Liidia Saluste, Ülle Kirss, Veiko Vasar. Seventeen-year-old boys' body fat content and its

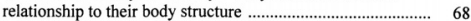

Jaan Loko, Rein Aule, Tõnu Sikkut, Raini Stamm. Stability of morphological characteristics and motor performance of 8-11-year-old girls (3-year longitudinal study) Eevi Maiste. Morphometry of heart and somatotypes of 15 -year-old schoolboys ..

Figure 5. Contents of the Yearbook of the Estonian Anthropometric Register 2000, p. 9 [4].

\section{CONTENTS}

Marina Aunapuu, Ennu Sepp. Morphological characteristics of varicose veins walls ...

Kaja Haljaste, Eve Pihl, Toivo Jürimäe. Anthropometric data and physical activity of former top-level swimmers Leiu Heapost. Osteometric data, stature and body proportions

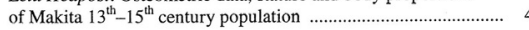
Mari Järvelaid. Impact of smoking on body stature of 16-18-year schoolchildren

Mari Järvelaid. Secular trend of body stature of Estonian schoolchildren

Jaak Jürimäe, Toivo Jürimäe. Relationships between body composition parameters and strength indices in middle-aged women

Toivo Jürimäe, Karl Sudi, Dorys Payerl, Jaak Jürimäe, Aire Leppik. Relationships between skinfold thicknesses measured by skinfold callipers and Lipometer

Jaan Kasmel. On the role of Prof. August Rauber's Institute of Anatomy in teatching anthropology at the University of Tartu

(Yuriev) in the first decades of the 20 century

Liidia Kiisk. Situation of diet nutrition in Tartu University

Hospitals

Ülle Kirss, Kandela Ôun. Comparison of 0-1-year-old children's body types by weight and height ...

Linda Kongo. Richard Jacob Weinberg - laureate of the K. E. v. Baer prize

Kristi Lehto. Growth curves of anthropological measures

of 0-13-month-old Estonian children

Figure 7. Contents of the Yearbook of the Estonian Anthropometric Register 2001, p. 9 [5].
10 Contents

Jarek Mäestu, Jaak Jürimäe, Toivo Jürimäe, Eve Pihl. The relationships between anthropometric variables and rowing
ergometer performance in male rowers .................................. 95

Jana Peterson, Säde Koskel. Health status and body build of 17-23-year-old women ............................................................. 107 Eve Pihl, Toivo Jürimäe. Abdominal fat distribution and cardiovascular disease risk factors in middle-aged men .......... 115 Merle Rehand, Toivo Jürimäe, Jaak Jürimäe, Eve Pihl, Karine Tammik, Aive Gross. Anthropometric parameters $\begin{array}{ll}\text { Karine Tammik, Alve Gross. Anthropometric parameters } & \\ \text { and aerobic capacity in women over } 70 \text { years of age ............. } 121\end{array}$ Helle -Evi Simovart, Eleonora Rajavee. Programmed cell death or apoptosis ..

Raini Stamm, Meelis Stamm, Säde Koskel. How to systematise the anthropometric data of 49 girl volleyballers aged 12-17 .. 151

Alvi Tellmann. Estonian Medical Birth Registry ......................... 156

Ene-Margit Tiit. Data and its value ............................................. 160

Milvi Visnapuu, Toivo Jürimäe. The relationships between anthropometry and motor activity in young handball players ....................................................... 169

Kandela Õun. An overview of the Estonian Anthropometric

Register ............................................................................ 177

Karin Mark in memoriam ......................................................... 179

Figure 6. Contents of the Yearbook of the Estonian Anthropometric Register 2000, p. 10 [4].

10 Contents

Karin Lilienberg, Merileid Saava. Trends in the

anthropometrical data of 14-year-old Tallinn schoolchildren ....... 115

Jana Limbo. Sexual dimorphism in dental size

at Pada cemetery 125

Mart Lintsi, Helje Kaarma, Liidia Saluste. Eighteen-year-old boys' body fat content by Omron®bf Body Logic Analyser and by Bodystat 500 estimated bioimpedance and their relationship to body structure ........................................................................... 14

Jaan Loko, Rein Aule, Tõnu Sikut, Raini Stamm. Height and

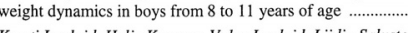

Kersti Loolaid, Helje Kaarma, Valve Loolaid, Liidia Saluste. Analysis of anthropometric data of 15-and 16-year-old Tartu

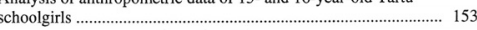
Eevi Maiste, Tiia Bakler. Dynamics of body build and heart morphometry in pubertal boys ............................................. 169

Kerttu Rahe, Anatoli Landõr, Jaan Loko, Servi Täll, Tõnu Kerttu Rahe, Anatoli Landõr, Jaan Loko, Servi Täll, Tõnu
Sikkut. Status of physical performance, physical abilities and Sikkut. Status of physical performance, physical abilities
attention qualities and correlations between them among attention qualities and correlations between them amon Raini Stamm, Meelis Stamm, Kaido Thomson, Ants Nurmekivi, Jaan Loko, Säde Koskel. Comparison of anthropometric data, test results and game proficiency of young female volleyballers

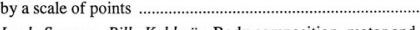
Lagle Suurorg, Pille Kaldmäe. Body composition, motor and musculosceletal health-related fitness of young Estonian males ... 201 Ene-Margit Tiit. Saving personal data in registries is it dangerous or useful? ........................................................... 209 Ene-Margit Tuit, Ene Käärik. Choice of the pregnant woman: to give birth or to have an abortion ........................................... 231 Maie Toomsalu. The birth of the old anatomical theatre and prof. Heinrich Friedrich Isenflamm .......................................... 242 Gudrun Veldre. Body build differences of 12-15-old Tartu boys and girls and comparison with earlier studies ....................... 262 Kandela Õun. Assessment of the anthropometric development of the foetus by recurrent ultrasound measurements ...................... 278

Figure 8. Contents of the Yearbook of the Estonian Anthropometric Register 2001, p. 10 [5]. 
CONTENTS

Liviva Born, Helje Kaarma, Säde Koskel, Mart Lintsi. Body build and body fat content in female patients at the Department of Cardiology at Tartu University Clinics

Leiu Heapost. Osteometry and reconstructed somatometry of Pada 12th-13th century cemetery .............................................................. 39 Ege Johanson, Merje Proosa, Mati Pääsuke, Jaan Ereline, Helena Gapeyeva, Nadezhda Ignatyeva. Relationship between back extensor muscle performance and anthropometric characteristics in

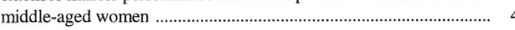
Jaak Jïrimäe, Toivo Jürimäe. Body composition parameters of male paddlers at the end of the preparatory period ........................... 51 Toivo Jürimäe, Karl Sudi, Doris Payerl, Jaak Jürimäe. Comparison of different body composition measurement methods in men and women .............................................................. 56

Pille Kaldmäe, Lagle Suurorg. Spirometry for diagnosing airway hyperreactivity in children ........................................................

Jaan Kasmel. Essays for Prof. A. Rauber Award at the Faculty of Medicine, University of Tartu .......................................................... 72

Linda Kongo. Christian Hermann Ludwig Stieda's activities in anthropology

A. Landõr, J. Vider, J. Maaroos, M. Lepik, T. Salum. The effect of the physical load, directed at the development of speed endurance, on blood parameters

Aire Leppik, Toivo Jürimäe, Jaak Jürimäe, Terje Sööt.

Relationships between bioelectrical impedance and anthropometric parameters in prepubertal children

Karin Lilienberg, Merileid Saava. Body mass index, plasma lipids and arterial blood pressure in Tallinn schoolchildren

epidemiological studies in 1984-1986 and 1998-1999

$$
2
$$

Figure 9. Contents of the Yearbook of the Estonian Anthropometric Register 2002, p. 9 [6].
10 Contents

Mart Lintsi, Helje Kaarma, Liidia Saluste. Multidimensional statistical models for classifying short 18-year-old boys into three weight classes — small, medium and large .................................... 132 Jaan Loko, Maili Tannbaum, Rein Aule. Tracking of somatic characteristics of 2-17-year-old boys .............................................. 145 Eevi Maiste. Athlete's heart ......................................................... 154 Kadri Ohvril. Assessment of changes in abdominal measurements during pregnancy by body mass index .......................................... 160 Mati Pääsuke, Jaan Ereline, Helena Gapeyeva, Heigo Maamägi. Relationship between muscle strength and anthropometric characteristics in young and middle-aged men ................................ 169 Merle Rosenthal, Mati Pääsuke, Jaan Ereline, Helena Gapeyeva. Relationship between leg extensor muscle strength and anthropometric characteristics in children with hearing disorders .... 177 Silvia Russak, Ene Indermitte, Astrid Saava. Dental fluorosis and caries among Tartu children in relation to drinking water fluoride

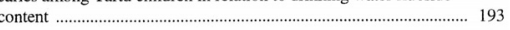
Urve Salundi. Body build structure of neonates .............................. 203 Liidia Saluste, Säde Koskel. Body build and body fat content of Tartu adult males and females in 1998-2001 (preliminary review) .............. 212 Raini Stamm, Meelis Stamm, Säde Koskel. Anthropometric models determining volleyball proficiency ............................................... 218 Lagle Suurorg, Sirje Tarraste, Mare Aaremäe. Peculiarities of heart rate variability in children ....................................................... 229 Ene-Margit Tiit. Creating a register on the basis of the Estonian Anthropometric Register ............................................................. 234 Maie Toomsalu. Bernhard Körber as a versatile scientist ................ 244 Maie Toomsalu. Morphologist Emil Woldemar Rosenberg ............ 250 Gudrun Veldre. Heath-Carter somatotypes in 12-15-year-old Tartu

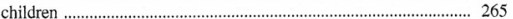
Milvi Visnapuu, Kristïne Ilves, Jaan Loko. Relations between somatic and motor performance in young handball players .............. 27

Figure 10. Contents of the Yearbook of the Estonian Anthropometric Register 2002, p. 10 [6].

In the introductions to the four Yearbooks published from 1999-2002, editorin-chief Prof. H. Kaarma has written respectively the following:

With the current Yearbook, we celebrate the 60th anniversary of foundation of the Anthropology Section at the Estonian Naturalists' Society by Juhan Aul [3];

As we have reached the third issue of the collection of anthropological studies in Estonian, I wish you continuing strength in developing this research area significant for our small nation [4];

In the fourth collection, the reader will find a greater number of articles than before; their themes continue to be diverse, which testifies to the vitality of the anthropological trend in health care and physical education [5];

The jubilee year - 200 years since the reopening of the University of Tartu has arrived; in a few years, the cradle of theoretical disciplines of the Faculty of Medicine, the Old Anatomical Theatre, will celebrate its 200th anniversary. For the following collections, we are looking forward to articles in Estonian on the history of science [6].

Below, we present the following summary about the Yearbooks of the Estonian Anthropometric Register (1998-2002). 
The covers of all the Yearbooks have been designed by Michael Walsh; the language editor was Leelo Jago.

From 1999, each article of the Yearbook is accompanied by a summary in English.

From 2002, the Yearbook of the Estonian Anthropometric Register was indexed in the database SPORTDiscus.

All the five Yearbooks were printed by Tartu University Press.

For general characterisation of the Yearbooks, we provide the number of pages, publications, first authors, co-authors, summative number of persons who were authors and first authors in each Yearbook separately and in five Yearbooks in total. The results are presented in the following Table.

Table 1. General characteristics of the Yearbooks of the Estonian Anthropometric Register (1998-2002)

\begin{tabular}{lcccccc}
\hline $\begin{array}{l}\text { Yearbook of the } \\
\text { Anthropometric Register }\end{array}$ & 1998 & 1999 & $\mathbf{2 0 0 0}$ & $\mathbf{2 0 0 1}$ & $\mathbf{2 0 0 1}$ & $\begin{array}{l}\text { Total in five } \\
\text { Yearbooks }\end{array}$ \\
\hline Pages & 160 & 233 & 185 & 279 & 272 & 1129 \\
\hline Number of publications & 27 & 24 & 21 & 26 & 27 & 125 \\
\hline First authors & 27 & 24 & 21 & 26 & 27 & 125 \\
\hline In addition, co-authors & 39 & 30 & 32 & 30 & 40 & 171 \\
\hline Total of authors & 66 & 54 & 53 & 56 & 67 & 296 \\
\hline Persons as 1st authors & 25 & 22 & 21 & 24 & 26 & 118 \\
\hline
\end{tabular}

Table 1 shows that the bulkiest Yearbook of the Estonian Anthropometric Register with 279 pages appeared in 2001. The most modest in its volume was the Yearbook of 1998 with 160 pages. In total, the five Yearbooks had 1129 pages.

The number of publications was the biggest in the Yearbooks of 1998 and $2002-27$ in both; the Yearbook of 2000 included only 21 publications. In total, 125 publications appeared in the five Yearbooks.

The number of first authors was the biggest in the Yearbooks of 1998 and 2002 - in both of them 27. Their number was the smallest 2000 - only 21. In total, the number of first authors in the five Yearbooks was 125.

The number of co-authors was the largest in 2002 when it was 40. Their number was the smallest in 1999 and $2001-30$ at both times. In total, the five Yearbooks had 171 co-authors.

The total number of authors was the largest in 2002 when there were 67 of them. Their number was the smallest in $2000-53$. The total number of authors in the five Yearbooks was 296. 
Table 1 shows that the number of first authors in the Yearbooks does not equal the number of persons who were first authors. The reason is that seven first authors had two publications in some years.

The number of persons as first authors was the greatest in the Yearbook of 2002 when it was 26 . Their number was the smallest in $2000-21$. The total number of persons as first authors in the five Yearbooks was 118.

In the Yearbook of 1988, 25 researchers as first authors published 27 articles; in the following four Yearbooks, they published respectively 16, 12, 12 and 11 articles - thus, a total of 78 articles in five Yearbooks.

In the Yearbooks of 1999-2002, the number of new first authors was respectively $7,8,8$ and 8 , making the total number of researchers 31 . The number of publications by them is respectively $14,14,11$ and $8-47$ articles in total.

Thus, we can say that 56 researchers as first authors published a total of 125 publications in the five Yearbooks (Part 2, Tables 3-7).

Along with the first authors of the articles published in the Yearbook of 1998 , there were 29 co-authors; in the following four years, the number of new co-authors was respectively 14, 10, 10 and 14; thus the five Yearbooks had a total of 77 co-authors (Part 2, Table 8).

Table 2. Distribution of articles in the Yearbooks of the Estonian Anthropometric Register (1998-2002) according to the number of authors

\begin{tabular}{lccccccc}
\hline $\begin{array}{l}\text { Number of } \\
\text { authors of } \\
\text { articles }\end{array}$ & 1998 & $\mathbf{1 9 9 9}$ & $\mathbf{2 0 0 0}$ & $\mathbf{2 0 0 1}$ & $\mathbf{2 0 0 1}$ & $\begin{array}{c}\text { Total of articles } \\
\text { per number } \\
\text { of authors }\end{array}$ & $\begin{array}{c}\text { \% of all the } \\
\text { articles in } \\
5 \text { Yearbooks }\end{array}$ \\
\hline 1 author & 11 & 10 & 6 & 12 & 10 & 49 & 39.2 \\
\hline 2 authors & 5 & 6 & 7 & 7 & 4 & 29 & 23.2 \\
\hline 3 authors & 3 & 4 & 2 & 2 & 6 & 17 & 13.6 \\
\hline 4 authors & 5 & 3 & 4 & 2 & 5 & 19 & 15.2 \\
\hline 5 authors & 2 & - & 1 & 2 & 1 & 6 & 4.8 \\
\hline 6 authors & 1 & - & 1 & 1 & 1 & 4 & 3.2 \\
\hline 7 authors & - & - & - & - & - & - & 0 \\
\hline 8 authors & 1 & - & - & - & - & - & 0.8 \\
\hline
\end{tabular}

Table 2 shows that the number of articles with one author was the largest in the Yearbook of $2001-12$. The number of such articles was the smallest in 2000 when it was 6 . In total, there were 49 articles by one author in the five Yearbooks, which accounted for $39.2 \%$ of all the published articles. 
The number of articles compiled by two authors was the biggest in 2000 and $2001-7$ in both years. Their number was the smallest in $2002-4$. In total, the number of articles with two authors in the five Yearbooks was $29-23.2 \%$ of all the published articles.

The number of articles with three authors was the biggest in 2002 when their number was 6 . The number of such articles was the smallest in 2000 and $2001-2$ in both years. The total number of articles with three authors in the five Yearbooks was $17-13.6 \%$ of all the articles.

The number of articles with four articles was the biggest in 1998 and 2002 5 at both times. Their number was the smallest 2001 - only 2 . In total, the number of articles with four authors in the five Yearbooks was $19-23.2 \%$ of all the articles.

The number of articles with five authors was the biggest in 1998 and 2001, at both times 5. The Yearbooks published in 2001 and 2002 both had one article with five authors. In total, the number of articles with five authors in the five Yearbooks was $6-4.8 \%$ of all the articles.

Articles with six authors were published in 1998 and 2000-2002, one in both years. In total, there were 4 articles with six authors in the Yearbooks, which makes $3.2 \%$ of all the articles.

The only article with eight authors was published in the Yearbook of 1999. It accounts for $0.8 \%$ of all the articles published in the five Yearbooks.

The overview of the development and preservation of Estonian as the language of higher education and research in anthropology, which dealt with the role of the Yearbooks of the Estonian Anthropometric Register in it, turned out longer than expected; therefore, we publish it in two parts.

The second part of the overview will include, in the form of tables, the distribution of articles by years according to their first authors, a list of co-authors and numbers of their participation in the articles of the Yearbooks, and the distribution of articles between the first authors from Tartu and Tallinn according to the institutions where they work.

\section{REFERENCES}

1. Ammon U. (2001). The Dominance of English as a Language of Science. Berlin: Mouton de Gruyter.

2. Eesti Antropomeetriaregistri Aastaraamat 1998 (1998). Tartu.

3. Eesti Antropomeetriaregistri Aastaraamat 1999 (1999). Tartu.

4. Eesti Antropomeetriaregistri Aastaraamat 2000 (2000). Tartu.

5. Eesti Antropomeetriaregistri Aastaraamat 2001 (2001). Tartu. 
6. Eesti Antropomeetriaregistri Aastaraamat 2002 (2002). Tartu.

7. Gibbs W. W. (1995). Lost science in the world. - Scientific American, August, 76-83.

8. Graddol D. (2000). The Future of English? London: The British Council.

9. Haarman H.; Holman E. (2001). The impact of English as a language of science in Finland and its role for the transition to network society. In: Ulrich Ammon (ed.). The Dominance of English as a Language of Science. Berlin: Mouton de Gruyter, 229-260.

10. Kaarma H. jt. (1998). TÜ füüsilise antropoloogia keskuse viieaastase töö kogemused ja edasised plaanid. In: Eesti Antropomeetriaregistri Aastaraamat 1998. Tartu.

11. Kasik R. (2015). Mida me oma kõrgharidusega siis nüüd teeme? Postimees, 27. august.

12. Kasmel J., Kasmel T. (2014). The year 1964 in the history of Estonian anthropology. Papers on Anthropology 23(2), 2-22.

13. Professor Juhan Aul. Kirjanduse nimestik 1919-1997 (1997). Tartu.

14. Zabrodskaja A. (2008). Teaduskeele seire Tallinna Ülikoolis: teadustöötajate hoiakud. In: Eesti Rakenduslingvistika Ühingu Aastaraamat, 4, 203-224.

\section{Address for correspondence:}

Jaan Kasmel

Centre for Physical Anthropology

University of Tartu

Struve 2, Tartu 51003, Estonia

E-mail: jaanjkasmel@hot.ee 